HORTICULTURE

\title{
Application of Molecular Markers and their Utility in Genetic Studies of Floricultural Crops: A Review
}

\author{
Mukesh Kumar ${ }^{1 *}$, Veena Chaudhary ${ }^{2}$, Ujjwal Sirohi ${ }^{3}$, V. Rakesh Sharma ${ }^{4}$ and \\ R.K. Naresh ${ }^{5}$
}

\begin{abstract}
${ }^{1}$ Department of Horticulture, Sardar Vallabhbhai Patel University of Agriculture \& Technology, Meerut, Uttar Pradesh, India ${ }^{2}$ Department of Chemistry, Meerut College, Meerut, Uttar Pradesh, India

${ }^{3}$ Department of Ag. Biotechnology, Sardar Vallabhbhai Patel University of Agriculture \& Technology, Meerut, Uttar Pradesh, India ${ }^{4}$ CSIR-NBRI, Lucknow, Uttar Pradesh, India

${ }^{5}$ Department of Agronomy, Sardar Vallabhbhai Patel University of Agriculture \& Technology, Meerut, Uttar Pradesh, India
\end{abstract}

*Corresponding author: k.mukesh123@yahoo.com (ORCID ID: 0000-0003-4539-9732)

Paper No. 788

Received: 14-04-2019

Revised: 16-07-2019

Accepted: 20-08-2019

\begin{abstract}
Understanding the genetics of floricultural germplasm represents a value added component of managing collections. Molecular approaches collectively represent a potential goldmine of important information that can be applied to programmes of genetic improvement. The development and utilization of molecular markers for the exploitation and identification of plant genetic diversity is one of the most key developments in the field of molecular genetics studies. Molecular markers are popular tool, due to their stability, cost-effectiveness and ease of use for a variety of applications in the field of molecular genetics. To know the role of molecular markers in genetic studies of floricultural crops, a number of molecular marker techniques have been reviewed by many researchers in worldwide. However, all these reviews were meant for researchers with advanced knowledge of molecular markers and their utility in limited aspects under floricultural crops. This review presents an overview of different marker technologies and their variants with a comparative account of their characteristic features and applications especially diverse molecular techniques used in assessing plant genetic diversity, inter-relationship between the genotypes, genetic purity, DNA barcode, tagging of important genes, development of linkage maps, marker assisted selection and application of molecular markers in tissue culture of floricultural crops. Altogether, the characteristics and types of markers with their applications and some recent advancement in genetic studies of floricultural crops are discussed.

\section{Highlights}

0 Molecular markers play an important role for assessing the genetic diversity and identification of desirable traits, inter-relationship between the genotypes and genetic purity analysis.

( Molecular markers can be helpful to develop a DNA barcode in flowering crops, tagging of qualitative genes, development of linkage maps, marker assisted selection and clonal fidelity analysis in tissue cultured flowering plants.
\end{abstract}

Keywords: Flowering crops, Characterization, DNA, genetic diversity, molecular markers, RAPD, ISSR SNP, SSR

Over the last thirty years, Biochemical markers such as isozymes were the first molecular tool to be used for genetic characterization of plants (Soltis and Soltis, 1990). Biochemical markers may also be biased since these markers represent a small portion of the genome and generally they exhibit low polymorphism. Molecular markers are considered to provide a better estimate of genetic diversity as they are unaffected by environmental factors, which affect the phenotype of plant. Molecular and DNA markers are either "dominant" or "co-dominant and play an important role in characterization and 
understanding of the genetic relationships between species and cultivars (Dore et al. 2001). Relative hetero-zygosity can thus not be measured directly with dominant markers. Co-dominant markers are defined for pairs of alleles. All genotypes (heterozygotes and both homozygotes) at a locus can be directly visualized. The comparison and characteristics of important molecular markers are listed in (Table 1). Some advantages of DNA markers are that they are not influenced by the environment, expressed in all tissues and can be scored at all stages of plant growth. Molecular approaches collectively represent a potential tool for assessing the important information that can be applied as an efficient tool for genetic studies in crop plants. Thus, giving new dimensions to breeding and marker-aided selection, that can reduce the time span of developing new and better varieties and the dream of super varieties come true. DNA markers offer several advantages over traditional phenotypic markers, as they provide data that can be analyzed objectively. Molecular markers provide a vast number of descriptors that can be used in addition to morphological data where these are unable to distinguish varieties/ germplasm. These markers are highly polymorphic and have been successfully used for genetic studies in many horticultural crops (Gulsen et al. 2007; Kumar et al. 2008 a and b, Kumar et al. 2013; Schafleitner et al. 2013; Kumar et al. 2014; Yadav et al. 2015; Sharma et al. 2016; Kumar et al. 2017 and Kumar et al. 2019) including flowering crops (Kiani et al. 2014; Kameswari et al. 2014; Kumar et al. 2016 and Kumar et al. 2018a and b). The objective of this review study was to (i) to describe different marker systems which are employed in (i) genetic relationship, genetic diversity, cultivar identification and genetic purity analysis; (ii) DNA bar coding, mapping and tagging of important genes (iii) marker assisted selection and development of linkage map and (iv) application of molecular markers in tissue culture of floricultural crops. Our goal was to assess the impact of markers and their use in genetic studies and utilized for various applications in the field of floriculture especially in crop improvement.

\section{Application of molecular markers in genetic studies of floricultural crops}

For agriculturally important species, a high level of allelic diversity provides an essential resource for mining beneficial trait variants associated with diversity. In the context of a changing climate, a

Table 1: Comparison of important characteristics of the most commonly used molecular markers

(Nadeem et al. 2018)

\begin{tabular}{|c|c|c|c|c|c|c|c|c|}
\hline Characteristics & RFLP & RAPD & AFLP & ISSR & SSR & SNP & DArT & $\begin{array}{c}\text { Retro } \\
\text { transposons }\end{array}$ \\
\hline $\begin{array}{l}\text { Co-dominant/ } \\
\text { Dominant }\end{array}$ & $\begin{array}{c}\text { Co- } \\
\text { dominant }\end{array}$ & Dominant & Dominant & Dominant & $\begin{array}{c}\text { Co- } \\
\text { dominant }\end{array}$ & $\begin{array}{c}\text { Co- } \\
\text { dominant }\end{array}$ & Dominant & Dominant \\
\hline Reproducibility & High & High & Intermediate & $\begin{array}{l}\text { Medium- } \\
\text { High }\end{array}$ & High & High & High & High \\
\hline Polymorphism level & Medium & Very high & High & High & High & High & High & High \\
\hline $\begin{array}{c}\text { Required DNA } \\
\text { quantity }\end{array}$ & High & Medium & Low & Low & Low & Low & Low & Low \\
\hline Marker index & Low & High & Medium & Medium & Medium & High & High & High \\
\hline Genome abundance & High & Very high & Very high & Medium & Medium & Very high & Very high & High \\
\hline Status & Past & Past & Past & Present & Present & Present & Present & Present \\
\hline PCR requirement & No & Yes & Yes & Yes & Yes & Yes & No & Yes \\
\hline Visualization & Radioactive & $\begin{array}{l}\text { Agarose } \\
\text { gel }\end{array}$ & Agarose gel & Agarose gel & $\begin{array}{l}\text { Agarose } \\
\text { gel }\end{array}$ & SNP-VISTA & Microarray & Agarose gel \\
\hline Required DNA (ng) & 10000 & 20 & $500-1000$ & 50 & 50 & 50 & 50-100 & $25-50$ \\
\hline
\end{tabular}


diverse germpalms set provides a valuable degree of genetic plasticity and adaptive potential for breeding-based crop improvements and future needs. Unfortunately, extensive artificial selection and inbreeding has severely limited the genetic diversity in many major floricultural crop species (He and Prakash 2001). Molecular markers are used as tools for a large number of applications including genetic diversity, genetic relationship, DNA barcoding, mapping and tagging of important genes, development of linkage maps, marker assisted selection and to assess the genetic fidelity and soma-clonal variation in tissue cultured plants. In the modern era of research on molecular biology, molecular marker-assisted section is a major achievement for scientists and breeders. Among the molecular markers, an ideal molecular markers should have following properties:

- Easily available;

- Assay is rapid and easy;

- Reproducible and highly polymorphic;

- Co-dominant inheritance and recurrent occurrence in genome;

- Selectively neutral to environmental conditions;

- Data exchange between different laboratories should be easy.

A number of molecular markers have been used for genetic studies which are discussed here.

\section{Molecular markers for genetic relationship analysis}

Molecular markers have been employed for genetic relationship studies in various floricultural crops. Yu et al. (2004) carried out DNA fingerprinting of five species of Dendrobium by AFLP primers. The combinations were screened from 64 primer combinations. Among the species, four species of Dendrobium were clustered into one big group, whose relationships were clearly distinguished. Qi et al. (2007) evaluated the genetic relationships of 12 Tagetes patula inbred lines including T. patula population $\mathrm{F}_{1}$, T. erecta population $\mathrm{F}_{2}$ with ISSR markers and morphological traits. The results obtained from ISSR and morphological traits indicated the same tendency. Jingang et al. (2008) ${ }^{\text {a }}$ analysed the genetic relationship of 26 cultivars of gladiolus by 19 ISSR markers. A total of 110 ISSR sites were detected with of 103 DNA fragments were polymorphic accounted $93.6 \%$ polymorphsm. Jingang et al. (2008) $)^{\mathrm{b}}$ used RAPD analysis to study the classification and genetic relationship of 26 cultivars of $G$. hybridus. A total of 206 RAPD sites were detected with a mean of 6.24 fragments amplified for each primer. A total of 185 polymorphic DNA fragments were detected among all the 206 amplified fragments, which accounted for a high level $(89.8 \%)$ of polymorphism and successfully identified all cultivars. Similarily, RAPDs and ISSRs markers were used by Patra et al. (2008) in canna and confirmed the genetic relationship among 10 cultivars of Canna. Braglia et al. (2010) assessed the genetic variation in a collection of $94 \mathrm{H}$. rosa-sinensis cultivars, and their phylogenetic relationships with other Hibiscus species by using AFLP markers. Three major clusters were identified: group A included 87 of the $94 \mathrm{H}$. rosa-sinensis cultivars, including within it two sub-clusters related to flower shape and size; group B included seven old $H$. rosa-sinensis cultivars together with $H$. storckii, considered to be their progenitor; and group $\mathrm{C}$ included $\mathrm{H}$. denisonii, H. kokio, H. genevii and H. liliiflorus together with $H$. boryanus, $H$. arnottianus and $H$. schizopetalus, have contributed to the wide genetic variability characteristic of $H$. rosa-sinensis. An application of molecular markers have been employed in gladiolus an ornamental bulbous flowering plant by Ranjan et al. (2010) who used amplified fragment length polymorphism (AFLP) markers to assess the genetic relatedness of 54 gladiolus cultivars. A total of 660 AFLP fragments were detected, of which 658 (99.70\%) polymorphic. All cultivars were clearly differentiated by their AFLP profiles. These findings were confirmed by Pragya et al. (2010) who observed the genetic relationships between 54 Gladiolus cultivars by RAPD markers. A total of 25 random amplified polymorphic DNA (RAPD) markers amplified and employed to discriminate between the cultivars and to evaluate the relatedness between them. A total of 225 RAPD bands (250-3000 bp) were obtained of which 211 polymorphic and 14 monomorphic generated $93.78 \%$ polymorphism. The similar patterns have been observed in other bulbous flowering plants like ornamental canna by Gupta et al. (2013) where AFLPs markers were used for genetic relationship and population structure analysis. The UPGMA clustering revealed 
four major groups accommodating 93\% cultivars and three cultivars each of different species i.e. $C$. argentina (NBC 24), C. latifolia (NBC 43) and one species i.e. C. generalis (NBC 13) didn't group with any clusters. Behroozian et al. (2013) investigated the genetic variation in 69 individuals of nine natural populations representing two species of Dianthus L by using RAPD markers. Furthermore, principal coordinate analysis (PCA) based on a Euclidean metric revealed that three populations of $D$. crinitus sub-sp. turcomanicus were genetically different from six populations of $D$. polylepis and observed that geographical distances, mating system and gene flow have important effects on genetic polymorphism of populations. A differentiation in species of bougainvillea was carried out by Kumar et al. (2014) who determined the genetic relatedness and molecular characterization of fifty bougainvillea cultivars that belong to four major species of bougainvillea namely B. glabra, B. spectabilis, B.peruviana and Bougainvillea $\times$ buttiana. Five microsatellite (simple sequence repeat; SSR) markers with high PIC values were used to characterize these bougainvillea cultivars. A total of 28 alleles were detected at an average number of alleles of 5.6 alleles /locus. The level of polymorphism among 50 bougainvillea cultivars was evaluated by calculating PIC values for each of SSR loci. The average PIC value was 0.716 per locus but the range of PIC values was 0.364 in Primer BOUG-5 to 0.891 in BOUG-1. High PIC value of BOUG-1 is reflecting its potential to better differentiate the cultivars at molecular level. From the PIC values it was evident that the allelic diversity is quite high among the bougainvillea cultivars. Prasad, (2014) find out the genetic relationship within the 9 varieties of Hibiscus rosasinensis through random amplified polymorphic (RAPD) markers. The genetic distance was very close within the varieties. Bhattacharyya and Kumaria, (2015) examined the genetic relatedness and genetic diversity of $60 \mathrm{D}$. nobile individuals from 6 natural populations by using 13 RAPD primers. The value of gene flow was low $(\mathrm{Nm}=0.27)$, the relative genetic diversity of the populations was high; the PIC was 0.74 while RP varied between 6.8 and 13.23. Molecular variations were higher between the populations $(62.21 \%)$ than within the populations $(37.79 \%)$ and the number of observed alleles was 1.95. However, the number of the alleles contributed to the genetic diversity was 1.54 . The
60 individuals' cultivars could be clustered into 2 main groups at $64 \%$ similarity. Singh et al. (2016) determined the relationships in 54 genotypes out of which nine gladiolus cultivars were using single primer amplification reaction methods (Random Amplified Polymorphic DNA-RAPD; Directed Amplification of Minisatellite DNA-DAMD; and Inter Simple Sequence Repeats-ISSR). A total of 30 primers (10-RAPD, 10-DAMD and 10-ISSR) resulted into 230 DNA fragments, of which 177 (75.8\%) were polymorphic in nature. Kumar et al. (2016) observed the genetic variation and relationship among 15 gladiolus genotypes by using nine inter simple sequence repeat (ISSR) markers. They reported that ISSR markers are very useful tool for genetic variation and relationship in gladiolus. The study carried out by Chaudhary et al. (2018) who used ISSR markers for genetic diversity and relationship among the 53 genotypes in gladiolus. The dendrogram based UPGMA clustering showed that all the 53 genotypes grouped into three main clusters. Nei's gene diversity $(\mathrm{Na})$ varied from 0.929 to 1.717 , effective number of alleles $(\mathrm{Ne})$ varied from 1.262 to 1.369 , Shannon's information index (I) ranged from 0.251 to 0.359 and gene diversity $(\mathrm{He})$ was in the range from 0.167 to 0.229 . Population structure analysis revealed three groups in which 32 genotypes were admixture types. The genetic relationship among genotypes, observed in the present study could be useful for designing particular breeding programme specially selection of parents. Clustered presence of exotic genotypes in the present study indicates that these genotypes harbor different genetic components that could be useful for the improvement of indigenous and development of novel genotypes.

\section{Molecular markers for genetic diversity assessment and cultivar identification}

Molecular markers are genetic loci that can be easily traced and measured in a population. It may be associated with a particular gene or trait of interest. Characterization of germplasm plays an important role in crop improvement programme. Assessment of genetic variation among the germplasm by molecular markers is also an important link between the conservation and utilization of plant genetic resources. It has been well documented that knowledge of genetic diversity and relationships 


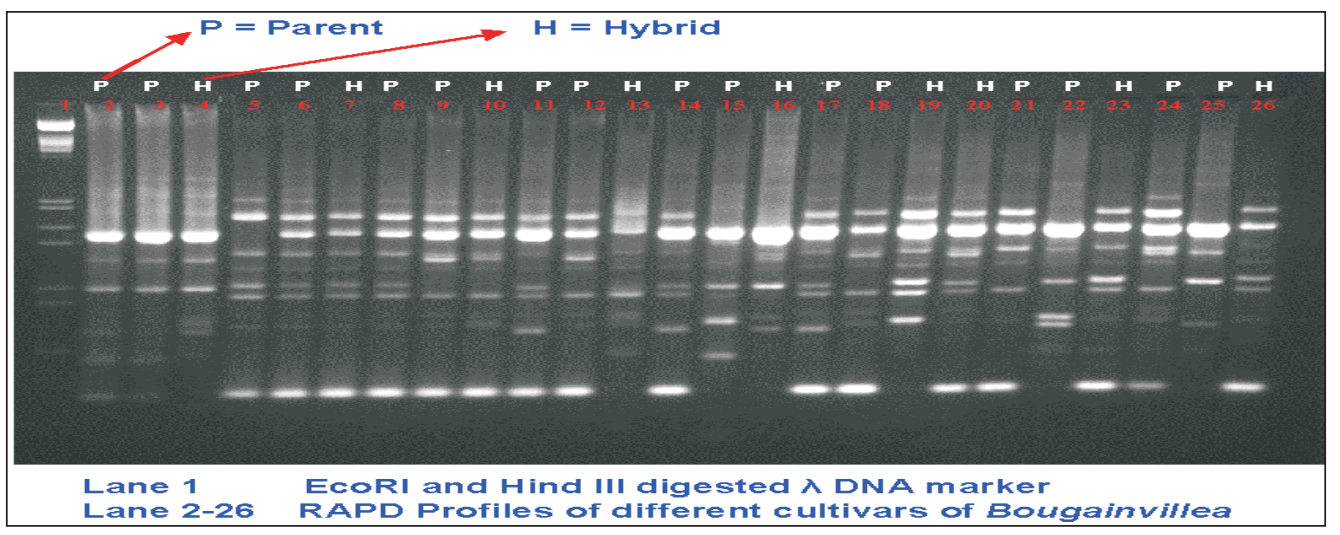

Fig. 1: RAPD profile of bougainvillea cultivars (Srivastava et al. 2009)

among germplasm is one of the most important process for identification of desirable traits in various crops including floricultural crops. It can be applied for selection of promising parents in hybrid variety and inbred line development, as well as registration of variety and protection (Pejic et al. 1998).

It has been reported in many studies that the larger part of morphological variability can not be measured consistently because of genotype $\times$ environmental interactions $(\mathrm{G} \times \mathrm{E})$ and the effects of a large number of quantitative genes. To obtain the desired traits, it was suggested that morphological variability must be eliminated because of the fact that most of genotypes look similar. Also, an increased number of cultivars, that are very close genetically, are difficult to differentiate, so morphological identification are arduous and extremely time-consuming. It was assisted in maintaining genetic diversity and sustained long term selection gain in a breeding programme (Chowdhury et al. 2002). Furthermore, evaluation and grouping of landraces of a crop from a certain region is helpful for studying the evolutionary relationships. Molecular markers have been proved as useful tool for evaluation of genetic diversity and cultivar identification in various floricultural crops (Baliyan et al. 2014 a, b, c Kumar et al. 2016; Kumar et al. 2017 Sirohi et al. 2017a, b; Chaudhary et al. 2018).

A molecular maker based study carried out by Smith et al. (2002) who revealed very low genetic diversity for terrestrial woodland orchid Tipularia discolor by ISSR markers. Polymorphism varied from 0.00 to $18.2 \%$ and gene diversity ranging from 0.00 to 0.069 . However, radio-mutant cultivars developed in chrysanthemum characterized by Lema-Ruminska (2004) who used RAPD markers to assess the difference between original and radio-mutants cultivars. Analysis of genetic similarity indices revealed low diversity within the radio-mutants. Moreover, PCR analysis proved the efficiency of the RAPD method for DNA fingerprinting of the original cultivar 'Richmond' and its new radiomutants. Chatterjee et al. (2007) screened fifty random decamer primers out of which ten were selected for final RAPD analysis in Bougainvillea. These ten primers used in this analysis yielded 167 scorable bands with an average of 11.3 bands per primer. A total of 167 fragments generated from these primers, out of 26 monomorphic and 141 polymorphic and resulted $84.4 \%$ polymorphism. Chen et al. (2009) observed the genetic diversity of 45 lily germplasm (21 wild species and 24 cultivars) using RAPD markers. A total of 28 polymorphic primers and one primer specific to the wild species were selected from 300 random primers, which generated 398 polymorphic bands. Wang et al. (2009) used 17 ISSR primers to assess the genetic diversity and phylogenetic relationships among 31 Dendrobium species. All species were unequivocally distinguished based on ISSR fingerprinting. UPGMA grouped the 31 Dendrobium species into six clusters, indicating the polyphyletic nature of the genus with several well-supported lineages. Li et al. (2014) assessed the genetic diversity of 28 cultivars of marigold (Tagetes patula L) by using SRAP (sequence-related amplified polymorphism) markers. A total of 271 scorable fragments were identified with 14 primer combinations, of which 151 (55.72\%) were polymorphic. Baliyan et al. (2014c) studied on genetic diversity in chrysanthemum by 


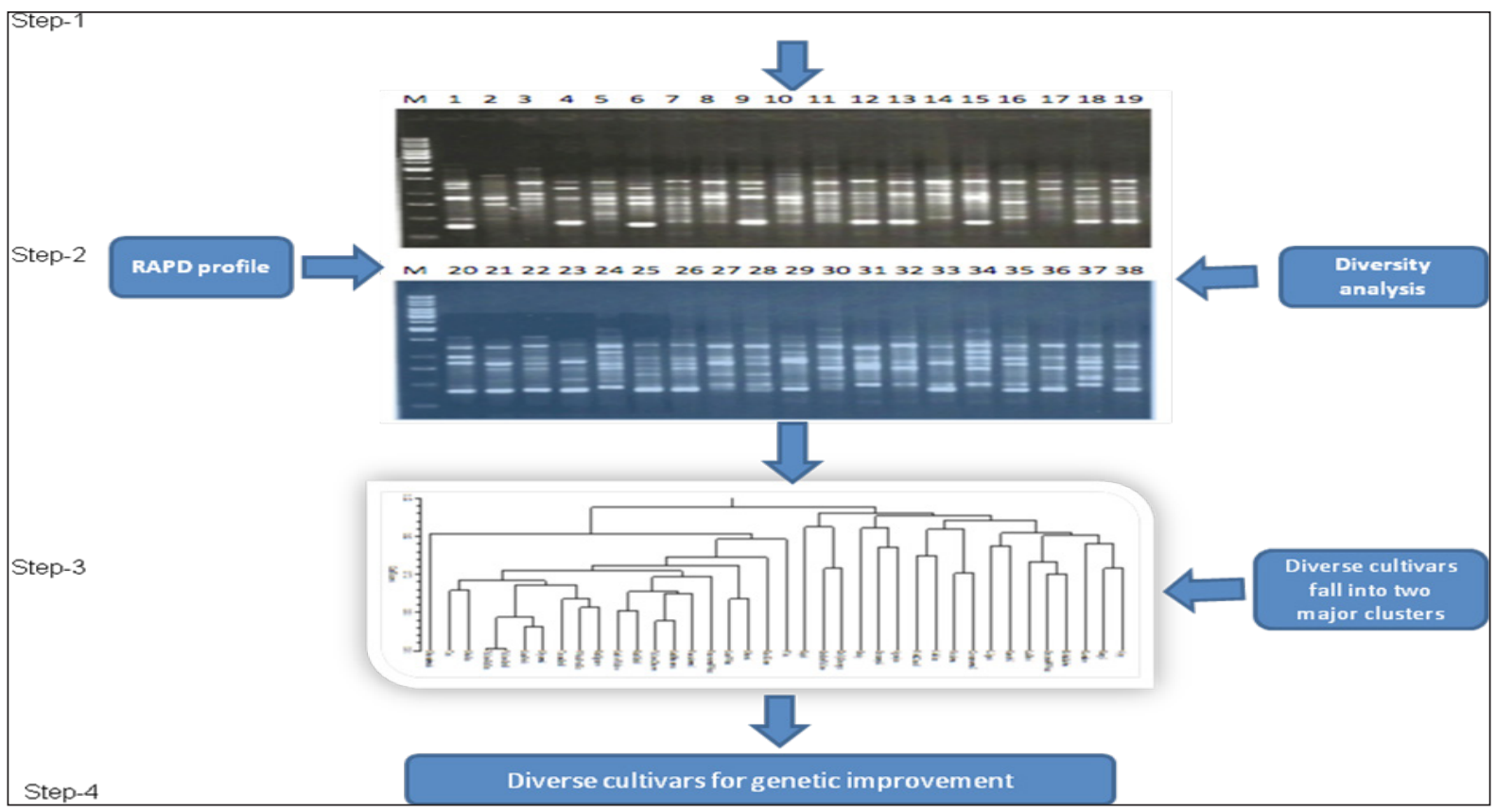

Fig. 2: DNA profiling and diversity analysis of chrysanthemum by RAPD markers (Kumar et al. 2017)

using morpho-agronomic traits and ISSR markers. The results revealed considerable differences among the genotypes for all the morphological traits. Diverse genotypes were identified namely SKC-83, Ratlam Selection, Gaity and Selection 69 at morphological and molecular analysis. The results further suggested that morphological traits and ISSR marker were highly useful for assessing the diverse genotypes and parental selection studies in chrysanthemum. Kumar et al. (2017) studied on genetic diversity and population structure in chrysanthemum. A total of 70 clear and scorable bands were produced by 10 RAPD primers (Fig.2). Out of 70 bands, 66 bands were polymorphic and four bands were monomorphic. All the 38 genotypes grouped two sub-populations and mixed population was observed among the genotypes. Panwar et al. (2017) characterized 22 genotypes of marigold (Tagetes erecta L.) by RAPD (randomly amplified polymorphic DNA) markers. A total of 26 RAPD markers were utilized for assessment of genetic divergence in marigold which amplified a total of 241 amplicons, out of which 238 (98.80\%) were found polymorphic.

\section{Molecular markers for genetic purity analysis}

A high quality seed plays an important role for better growth yield and quality of various crops. High quality seed can be obtained only by a thorough control of the entire seed production process at every step from planning to final delivery. Traditionally, genetic purity of seeds by seed companies are carried out by the evaluation of morphological or physiological traits expressed by seed, seedlings or mature plants. McDonald (1995) observed the field testing under uncertain environmental conditions during seedling/plant development by expression of specific morphological or physiological traits.

Molecular markers, based on DNA sequences (Botstein et al. 1980) provide a genetic diagnostic tool that permits direct identification of a genotype in an environment independent manner in any tissue at any developmental stage. Molecular markers have been used for genetic purity and pedigree analysis in many flowering crops. Yamagishi, (1995) utilized the Random amplified polymorphic DNA (RAPD) markers for identification of Lilium species and inter-specific hybrids. Among 76 primers used to amplify genomic DNA by PCR, 18 primers (24\%) generated polymorphic DNA fragments in Lilium species and hybrids. Seven inter-section hybrids showed the section-specific bands of both parental sections, indicating that these markers would be useful for identifying the parental sections of inter-section hybrids. Genetic analysis of tropical orchid hybrids (Dendrobium) with Fluorescence Amplified Fragment-length Polymorphism (AFLP) was carried out by Xiang and Hong (2003) in 43 
popular commercial Dendrobium hybrids to assess their genetic relationship. The hybrids bearing flowers of similar shapes and colors were clustered into five groups. Each hybrid tested had a distinct AFLP fingerprint profile except the tissue culture mutants. Sibling hybrids were closely clustered (with genetic distance $<0.09$ ) followed by those sharing one parent. These results suggest that AFLP fingerprint profiling gives accurate and objective estimation of genetic relationship of the Dendrobium hybrids tested. Lee et al. (2005) studied on 55 interspecific hybrids between Dianthus giganteus and D. carthusianorum using RAPD markers. They detected 216 polymorphic RAPD bands and found that the mostly inter-specific hybrids exhibited intermediate characteristics between parents.

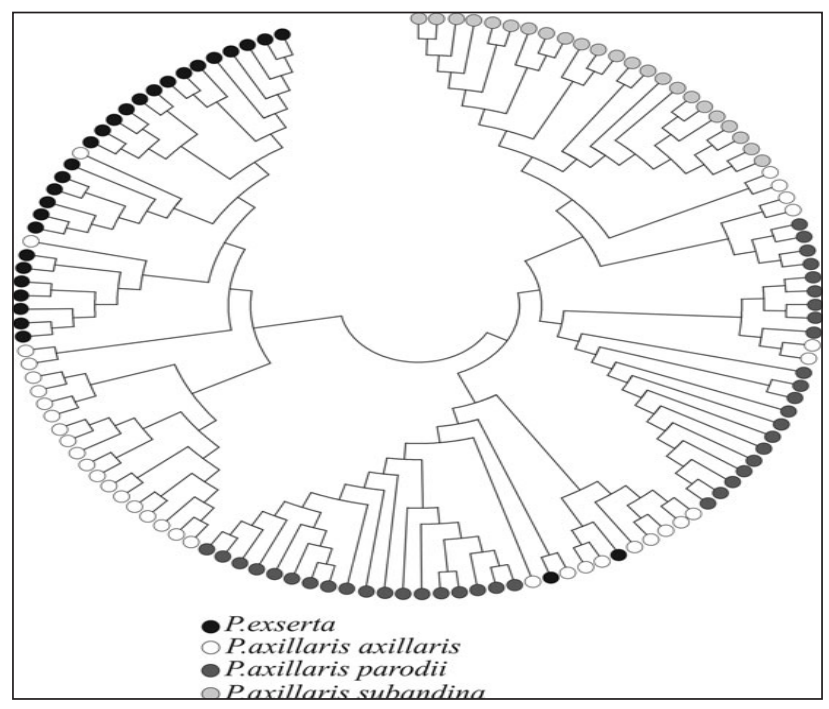

Fig. 3: Neighbour-joining tree of 126 individuals of petunia (coloured by taxon), constructed based on a matrix of microsatellite alleles shared among individuals (Turchetto et al. 2015).

Barik et al. (2006) also found the genetic variation within the two species of Hibiscus and 16 varieties of Hibiscus rosa-sinensis L. through random amplified polymorphic (RAPD) markers. However, cluster analysis indicated that 16 varieties and two species formed one cluster. The first major cluster consisted of three varieties and second major cluster consisted of two species and 13 varieties. Thirteen Microsatellites or SSR (simple sequence repeat markers) developed by Kimura et al. (2009) in carnation by enriched genomic library method and its use for hybrid analysis. The parentage of two carnation mutant varieties obtained from intra-specific crosses and hybridity of the progenic varieties was confirmed by SSR markers. Srivastava et al. (2009) studied on genetic relationships in different Bougainvillea cultivars including hybrids by using DNA markers. The results revealed that Group A had three cultivars namely Trinidad, Formosa and Dr. H.B. Singh in which Dr. H.B. Singh was confirmed as a hybrid of other two cultivars. Group B was sub divided into 8 clusters. The parentages of 7 out of 8 hybirds have been confirmed based on clusters. It can be concluded that the RAPD technique is suitable for confirmation of parent-hybrid relationship.

Turchetto et al. (2015) analysed two closely related species of Petunia exserta, which has a narrow endemic range and grows exclusively in rocky shelters, and Petunia axillaris, which was widely distributed and comprises three allopatric subspecies by EST-SSRs markers. Four major groups were identified in clustering analyses, which indicated that there are genetic distinctions among the groups (Fig.3). The EST-SSR markers scattered throughout the Petunia genome are very efficient tools for characterizing the genetic diversity in wild taxa of this genus and aid in identifying interspecific hybrids based on the presence of private alleles. Jedrzejuk et al. (2017) investigated the inter-specific hybrids developed between Petunia and Calibrachoa by using four different introns with flanking exon areas, each from a different gene and with a different sequence for Petunia and Calibrachoa, as genus-specific markers for chromosomes in interspecific hybrids. PCR primers specific for Petunia and Calabrachoa were tested on a range of presumed hybrids using multiplex PCR, which confirmed that the hybrids were derived from these two species. Flow cytometry demonstrated that the hybrids were triploid, and determination of chromosome numbers showed that two of the chromosome sets were from Calibrachoa, i.e. that the other parent, Petunia, was diploid. Similar methods can be used for molecular characterization of other new hybrids made between closely related species or cultivars.

\section{Molecular markers for DNA bar-coding}

Proper characterization and best documentation of floricultural crops, DNA barcoding will be one day become both a practical solution to the taxonomic impediment and a routine procedure. 
However, barcoding today, especially in plants, is still firmly within the realm of scientific research. DNA barcoding has already proved as useful tool to attract the attention of the DNA barcoding community. It is difficult to determine whether similar looking species from different locations are the same or different. DNA barcoding can be helpful to provide a test of specificity. Morphospecies approach with DNA barcoding can be used to undertake rapid assessment of new biodiversity. Thus, DNA barcoding can speed up identification of new species, cultivars, genotypes and plant germplasm. It can be linked to readily observable morphological characters and can provide an avenue to encourage new participants into taxonomy.

Two general categories of potential users of DNA barcodes: plant taxonomists, who wish to use these markers as tools to elucidate species limits, and scientists in other fields, who uses taxonomic concepts developed by taxonomists for the purpose of genetic improvement or plant processes. Barcoding provides a rapid assessment without the need for detailed morphological expertise in the first instance. To the best of author knowledge, very little work have been carried in floricultural crops on DNA barcoding. DNA barcoding have been successfully applied to identify orchids species (Yao et al. 2009; Parveen et al. 2012). In earlier, CBOL a Plant Working Group recommended the two-loci combination of $r b c L+$ matK as plant DNA barcodes, which are sequences that vary extensively between species but hardly at all within them (CBOL Plant Working Group, 2009). DNA barcoding may be helpful to identify plant species and also provide taxonomic information that would allow their evolutionary relevance to be clarified (Chase et al. 2005; Vogler and Monaghan, 2007). However, Huang et al. (2010) reported that ITS sequence could be used as a potential barcode for identifying Dendrobium species by inter- and intraspecific divergences. Neither $r b c L$ nor matK and $\operatorname{trnH}-p s b A$ can be used to identify Dendrobium on its own. No single sequence could completely identify different types of Dendrobium species and the combination of different sequences as a DNA barcodes for Dendrobium are in needed. Singh et al. (2012) tested six recommended loci that have been suggested as possible universal DNA barcodes for plants, namely matK, rbcL, rpoB, rpoC1, trn $H$ -
psbA spacer from the chloroplast genome and ITS, from the nuclear genome, and noted that only ITS was able to effectively discriminate all tested 36 Dendrobium species. de Vere et al. (2012) developed a national DNA barcode of native flowering plants and conifers for the nation of Wales (1143 species) by using the plant DNA barcode markers i.e. $r b c L$ and $m a t K$. The findings assembled $97.7 \%$ coverage for $r b c L, 90.2 \%$ for $m a t K$, and a dual-locus barcode for $89.7 \%$ of the native Welsh flora. The sampled multiple individuals for each species, resulting in $3304 \mathrm{rbcL}$ and 2419 matK sequences. Recoverability of DNA barcodes was lower using herbarium specimens as compared to freshly collected material, mostly due to lower amplification success. The effectiveness of the DNA barcodes for identification was assessed using following approaches: the presence of a barcode gap, formation of monophyletic groups using Neighbour-Joining trees, and sequence similarity in BLASTn searches. These approaches yielded similar results, providing relative discrimination levels of 69.4 to $74.9 \%$ of all species and 98.6 to $99.8 \%$ of genera using both markers. Mean species discrimination using barcode gap analysis was $81.6 \%$ within $10610 \mathrm{~km}^{2}$ and $93.3 \%$ for $262 \mathrm{~km}^{2}$. Khandagale et al. (2014) constructed cultivar identification diagram (CID) by using 11 ISSR primers which gave 57 highly reproducible polymorphic bands in ten tuberose varieties, with specific sizes to separate the varieties. Molecular size of each of the fragments was estimated using UVpro software (UVTECH, UK). CID construction was done based on presence (+) and absence (-) of polymorphic loci. Cultivars sharing the same banding pattern were clustered into one sub-group and subsequently, more markers employed to distinguish cultivars within each sub-group. Further, these 11 ISSR markers were used for developing molecular barcodes to fingerprint tuberose varieties. Binary data thus produced is represented as bar for presence and absence of band was kept blank. Li et al. (2017) tested two main candidate DNA barcodes (ITS2 and $p s b A$-trnH) to identify twenty-one cutting cultivars of $P$. lactiflora and their wild species. The efficacy of the candidate DNA barcodes was assessed by PCR amplification, sequence quality, sequence diversity, rate of correct identification and phylogenetic analysis. ITS2 was easy to be amplified and sequenced among the samples. The identification by BLASTn and phylogenetic analysis 
was $95.4 \%$ and $63.6 \%$, respectively. For psbA-trnH, the presence of poly A-T led to sequencing failure which limited its use as DNA barcode candidate. Moreover, the authentic efficiency of $p s b A-t r n H$ was lower than ITS2. The results also suggested that ITS2 is suitable as a candidate DNA barcode for the intra-specific identification of P. lactiflora cultivars.

Elansari et al. (2017) reported the standard plant barcode markers (matK and $r b c L$ ) for the identification of plant species in private and public nurseries. These two markers were sequenced from 225 specimens, out of 161 species and 62 plant families of horticultural importance. The sequence recovery was similar for $r b c L(96.4 \%)$ and $m a t K$ $(84 \%)$, but the number of specimens assigned correctly to the respective genera and species was lower for $r b c L$ (75\% and $29 \%$ ) than matK (85\% and $40 \%$ ). The combination of $r b c L$ and matK brought the number of correct generic and species assignments to $83.4 \%$ and $40 \%$, respectively. Individually, the efficiency of both markers varied among different plant families. For future, it is recommend that the combination of a complementary barcode (e.g. ITS or $t r n H-p s b A$ ) with $r b c L+m a t K$ should be applied to increase the performance of taxa identification. By aiding species identification of horticultural crops and ornamental palms, the analysis of the barcode regions will have large impact on horticultural industry.

\section{Molecular markers for mapping and tagging of genes}

Tagging of useful genes like the ones responsible for flower colour, longevity of flowers, flower fragrance, flower size, synthesis of plant hormones, drought tolerance and variety of other important developmental pathway genes is a major target. Such tagged genes can also be used to develop a hybrid for desirable traits. Gene tagging is a prerequisite for MAS and map based gene cloning.

Molecular markers have been used for tagging and mapping of important genes in many floricultural crops. An isolate-specific powdery mildew resistance gene, Rpp1, was identified by (Linde et al. 2004) and mapped using 117 diploid roses of the population $97 / 9$ originated from a cross of the diploid line 88/124-46, resistant against the powdery mildew. Onozaki et al. (2003) also found that RAPD markers associated with genes controlling wilt resistance in a resistance-segregating population and they further suggested that at least 3 genes are concerned with resistance to bacterial wilt. These markers can be useful for marker-assisted selection in carnation. Wang et al. (2010) developed a stable system for identification the genes related to fertility in Tagetes erecta. A total of 100 sterile and fertile plants alongwith W205, a two type male sterile line in Tagetes erecta were tested. Two hundred eighty eight bands were obtained by using 64 RAPD primers, among which one band of $980 \mathrm{bp}$ derived from the primer G-02(5'-GGCACTGAGG-3') was cosegregating with fertile plants. This RAPD marker named as G-02-980 could be used to identify male and fertile seedlings. Chong et al. (2016) identified six genes for three important traits (ray floret type, cultivated type and flower shape), but no association with flower color was detected in chrysanthemum. Chong et al. (2019) developed a total of 81 SNPs which were significantly associated with the three inflorescence-related traits (capitulum diameter, number of ray florets and flowering time) in at least one environment. Two highly favorable SNP alleles correlating to flowering time and capitulum diameter were converted to derive cleaved amplified polymorphic sequence (dCAPS) markers to facilitate future breeding. Finally, six putative candidate genes were identified that contribute to flowering time and capitulum diameter.

\section{Molecular markers in marker assisted selection}

Marker assisted selection (MAS) refer to the use of DNA markers that are tightly-linked to target loci as a substitute for or to assist phenotypic screening. These DNA markers should reliably predict phenotype. By determining the allele of a DNA marker, plants that possess particular genes or quantitative trait loci (QTLs) may be identified based on their genotype rather than their phenotype. A marker can either be located within the gene of interest or be linked to a gene determining a trait of interest, which is the most common case. Thus, MAS can be defined as selection for a trait based on genotype using associated markers rather than the phenotype of the trait. Ballard et al. (1996) also found that molecular markers associated with black-spot resistance in roses using genotypes of different ploidy levels and differing in resistance/ susceptibility. RAPD analysis of the parental rose 
plants of the crosses showed a high degree of genetic polymorphism between all the resistant amphidiploids and susceptible tetraploid parent cultivars and further suggested that progeny produced from a cross between any 2 resistant and susceptible parents would be suitable for genetic map construction. However, Malek et al. (2000) screened tetraploid progeny (95/3) segregating for the presence of the black-spot resistance gene $R d r 1$ with 868 RAPD and 114 AFLP primers/primer combinations. Seven AFLP markers were found to be linked to $R d r 1$ at distances between 1.1 and $7.6 \mathrm{cM}$. The most closely linked AFLP marker was cloned and converted into a SCAR marker that could be screened in a larger population than the original AFLP, and was linked at a distance of 0.76 $\mathrm{cM}$. The cloned fragment was used as an RFLP probe to locate the marker on a chromosome map of diploid roses. Another study carried out by Scovel et al. (2001) who used a segregating $\mathrm{F}_{2}$ population derived from a cross between a resistant and a sensitive parent. To assess the results, a field test was performed which enabled phenotypic scoring following natural inoculation of the progeny. Based on the hypothesized model and by focusing on the extreme segregants, one of the major genes for resistance was tagged using random oligonucleotide primers. Linkage was established by examining the entire $F_{2}$ family using a standard t-test. $F_{3}$ populations derived from selected $\mathrm{F}_{2}$ segregants were used to verify linkage and to identify of $\mathrm{F}_{2}$ segregants homozygous for the marker. The RAPD fragment was sequenced and used to synthesize sequence-specific primers i.e. PCR-based, SCAR marker for resistance analysis. The same fragment was also used as a probe for a southern blot analysis and RFLP marker was established for co-segregated with the resistant progeny. By exploiting the existing $\mathrm{F}_{2}$ family, containing the tagged locus, it should now be possible to develop an additional marker.

Simple Sequence Repeats (SSRs) markers were developed by Biber et al. (2010) which were tightly linked to $R d r 1$, and found suitable for genetic analyses and marker-assisted selection in roses. As a source for the high molecular weight DNA, they chose the homozygous resistant $R$. multiflora hybrid $88 / 124-46$. In order to increase the resolution for fine mapping, the size of the population was increased upto 974 plants. The genomic region spanning
$R d r 1$ is now genetically restricted to $0.2 \mathrm{cM}$, corresponding to a physical distance of about $300 \mathrm{~kb}$. One single stranded conformational polymorphism (SSCP) and one SSR marker co-segregate with the Rdr1-mediated black spot resistance, while one SSR and several cleaved amplified polymorphic sequence or SSCP markers are very tightly linked with one to three recombinants among the 974 plants.

Tasaki et al. (2017) developed a PCR-based molecular DNA marker to distinguish double- and singleflower phenotypes at the young seedling stage in Japanese gentian plants. To test the validity of the markers, $17 \mathrm{~F}_{2}$ populations were produced by selfing $\mathrm{F}_{1}$ plants crossed between the double-flower mutant and seven breeding lines. Multiplex PCR demonstrated that the Tgs1 insertion in GsAG1 cosegregated with the double-flower phenotype in two $\mathrm{F}_{2}$ populations, indicating that the PCR-based DNA marker was useful to discriminate between double- and single-flower phenotypes in advance of flowering in Japanese gentian. Due to lack variation in Japanese gentians flower shape and require a long breeding period, the developed DNA marker may be helpful for efficient breeding programme for development of double-flowered cultivars in the future. The findings also revealed that a doubleflowered mutant of Gentiana scabra was caused by an insertion of a retro-transposable element (Tgs1) into GsAG1, one of the C-class MADS-box genes in gentian. Zheng et al. (2019) developed $\left(\mathrm{F}_{1}\right)$ population from Lagerstroemia fauriei Koehne (standard) and L. indica "Creole" (creeping) and the backcross1 $\left(\mathrm{BC}_{1}\right)$ population was derived from the backcross of $\mathrm{F}_{1}$ individual $\mathrm{S} 82$ (creeping) and L. fauriei. The segregation of the creeping trait was analyzed for 174 seedlings of the $\mathrm{BC}_{1}$ population to examine the linkage relationship between simple sequence repeat (SSR) molecular markers and the creeping trait. Creeping genes were screened using bulked segregant analysis combined with 322 SSR primers, which were detected with good polymorphism. The results show that two SSR markers (S364 and LYS12) were detected, with genetic distances of 23.49 centimorgan $(\mathrm{cM})$ and $25.86 \mathrm{cM}$ from the loci controlling the plant opening angle trait and the branching angle trait, respectively. The accuracy rate for phenotypic verification using S364 and LYS12 was $76.51 \%$ and $74.14 \%$, respectively. 


\section{Molecular markers for development of linkage map}

It's a graphical representation of an array of loci, segregating populations, including $\mathrm{F}_{2}$ generations, backcross progeny, recombinant inbred lines, etc. (Lefort-Buson et al. 1990). The construction of a marker linkage map provides a tool to identify the structural organization of genome. Markers on the same chromosomes are linked while markers on different chromosomes are separated. The relative distance between two markers is evaluated by their recombination rate. Using the molecular technique, the selection of plant material depends on the biology of the species. Molecular markers have been successfully used for development of genetic linkage maps in various floricultural crops (Fig.4). Among the flowering crops, Shahin et al. (2009) developed a genetic map in Asiatic Hybrid lily with an intra-specific Asiatic backcross population by using three different molecular marker systems (DArT, AFLP and NBS profiling) and four QTLs for Fusarium oxysporum and one locus for $\mathrm{LMoV}$ which localized on this map. The most tightly linked markers to the most significant two Fusarium QTLs in the AA population were converted into more robust PCR markers. PCR-based DNA markers were examined on two cultivars of Asiatic Hybrid lily using random primers. A genetic map constructed by (Van Heusden et al. 2002) with 251 AFLP markers on 100 descendants of a lily backcross population and four Fusarium resistance- QTLs mapped on linkage groups of 1,5,13 and 16.This map was improved later in 2011 by application of diversity arrays technology (DArT) and nucleotide binding site (NBS) profiling and AFLP markers (Shahin et al. 2011).

Xue et al. (2010) constructed a genetic map of two Dendrobium species with a double pseudo-testcross strategy using RAPD and SRAP markers. $\mathrm{F}_{1}$ mapping population (90 individuals) was developed from a cross between both species. A total of 307 markers, including 209 RAPD and 98 SRAP, were used for genetic linkage group analysis. The $D$. officinale linkage map consisted of 11 major linkage groups and 3 doublets, covering $629.4 \mathrm{cM}$ using a total of 62 markers with an average locus distance of $11.2 \mathrm{cM}$ between two adjacent markers. The $D$. hercoglossum linkage map had 112 markers and mapped on 15 major and 4 minor linkage groups, spanning a total length of $1304.6 \mathrm{cM}$ with an average distance of $11.6 \mathrm{cM}$ between two adjacent markers. The maps covered $92.7 \%$ and $82.7 \%$ of the D. hercoglossum and D. officinale genomes, respectively. Lu et al. (2012) developed an integrated genetic linkage map of an $\mathrm{F}_{1}$ population derived from an inter-specific cross between $D$. officinale and D. aduncum (both, $2 n=38$ ). Genetic map was constructed by using expressed sequence tag-simple sequence repeats (EST-SSR) and sequence related amplified polymorphism (SRAP). A total of 349 polymorphic loci, including 261 SRAP loci and 88 EST-SSR loci, were identified for genetic linkage analysis. A total of 157 loci were arranged into 27 major linkage groups, each containing a minimum of four markers, and a further 23 markers were distributed to five triplets and four doublets, the frame map covered with a total distance of $1580.4 \mathrm{cM}$, with a mean of $11.89 \mathrm{cM}$ between adjacent markers. This primary map of the D. officinale and D. aduncum hybrid provides a basis for genetic studies and also facilitate future studies of important traits mapping and marker-assisted selection in Dendrobium species breeding programs. Feng et al. (2013) constructed two preliminary genetic linkage by using $90 \mathrm{~F}_{1}$ progeny individuals derived from an inter-specific cross between $D$. nobile and $D$. moniliforme (both, $2 \mathrm{n}=38$ ), using random amplified polymorphic DNA (RAPD) and inter-simple sequence repeat (ISSR). A total of 286 RAPD loci and 68 ISSR loci were identified and used for genetic linkage analysis. The frame map of $D$. nobile was $1474 \mathrm{cM}$ in total length with 116 loci distributed in 15 linkage groups; and the $D$. moniliforme linkage map had 117 loci placed in 16 linkage groups spanning $1326.5 \mathrm{cM}$. Both maps showed $76.91 \%$ and $73.59 \%$ genome coverage for D. nobile and D. moniliforme, respectively. A highdensity integrated map for diploid roses was generated by Yan et al. (2018) who used thousands of informative single nucleotide polymorphism (SNP) markers. These SNPs along with known bridge simple sequence repeat (SSR) markers allowed us to create the first high-density integrated consensus map for diploid roses. Individual maps were first created for populations J06-20-14-3 ${ }^{\prime \prime}$ Little Chief" (J14-3×LC), J06-20-14-3x"Vineyard Song" $(\mathrm{J} 14-3 \times \mathrm{VS})$ and "Old Blush" $\times$ "Red Fairy" $(\mathrm{OB} \times \mathrm{RF})$ and these maps were linked with 824 SNPs and 13 SSR bridge markers. The anchor SSR markers were used to determine the numbering of the rose linkage 
groups. The diploid consensus map has seven linkage groups (LGs), a total length of $892.2 \mathrm{cM}$, and an average distance of $0.25 \mathrm{cM}$ between 3527 markers. This consensus map will serve as the tool for the discovery of marker-trait associations in rose breeding using pedigree-based analysis.

\section{Molecular markers in tissue culture}

For commercial utilization of in vitro propagation, it's essential to raise an adequate amount of disease free planting material of true-to-type newly developed elite lines. The applicability and sustainable use of micro-propagated plants would eventually depend on the relative field performance compared to that of the conventionally propagated plants (Zaman et al. 1997). A major problem associated with in vitro culture is the occurrence of genetic variation resulting from micro-propagation, i.e., somaclonal variation amongst sub-clones of one parental line, arising as a direct consequence of in vitro culture of plant cells, tissues and organs (Gould 1986). Somaclonal variations occur mostly in response to the stresses imposed on the plant under in vitro conditions and is manifested in the form of DNA methylations, chromosome re-arrangements and point mutations (Phillips et al. 1994). A stringent quality check in terms of genetic similarity of the tissue culture raised plants becomes mandatory. Identification of off-types and genetically trueto-type of mother plant at an early stage of development is considered to be very useful for quality control in plant tissue culture. Therefore, it is also necessary to check the genetic uniformity of micro-propagated plants by molecular techniques. A number of studies have been carried out to assess the genetic fidelity, genetic stability and somaclonal variation in various flowering crops.

Genetic variation study in vitro raised plant lets carried out Senapati and Rout (2008) who detected the genetic variation in vitro raised plants by using RAPD markers and obtained 21.5\% polymorphism among the vitro raised plants. There was morphological variation between mutant and control plants, with regard to plants height, number of branches, number of flowers, stalk length of the flower, leaf size and number of petals/flower. However, Gantait and Sinniah (2011) exhibited no variation in plants at ploidy level established through flow cytometric. Genetic assessment through ISSR showed no polymorphism in banding pattern. The results revealed that there was no significant variation among micropropagated and seed propagated plants at ploidy level and molecular level assuring the trueness of the micro-propagated anthurium clones and their commercial applicability. Liu et al. (2011) assessed the genetic stability of 32 plantlets of Hydrangea macrophylla by 44 ISSR markers. Out of 44 ISSR markers, ten markers produced clear, reproducible bands with a mean of 5.9 bands per marker. Thirtytwo regenerates did not deviate at all from the parental genotype due to monomorphic bands. A micro-propagation study was carried out by Memon et al. (2012) in three gladiolus cultivars to assess the percentage of clonal fidelity each other in cultivars namely, Traderhorn, White Friendship and Peter Pears and with vitro generated mother cormels using Random Amplified Polymorphic DNA (RAPD) and Inter Simple Sequence Repeat (ISSR) markers. The RAPD similarity tendencies among In vitro propagated cormels ranged from $80 \%$ to $95 \%$ in Traderhorn, $88 \%$ to $95 \%$ in White Friendship and $80 \%$ to $90 \%$ in Peter Pears. However the similarity tendencies between mother and in vitro propagated cormels, on average were $86 \%$ in Traderhorn, 92\% in White Friendship and $83 \%$ in Peter Pears. The ISSR cluster analysis for genetic similarity between mother and in vitro propagated cormels had varied degree of differences detected 90\% in Traderhorn, 96\% in White Friendship and 85\% in Peter Pears. The genetic differences among in vitro propagated cormels ranged from 88 to $100 \%$ in Traderhorn, 94 to $100 \%$ in White Friendship and 82 to 100\% in Peter Pears. Yin et al. (2013) observed genetic stability in the regenerates of lilium cultivar of "Siberia". No polymorphic bands were detected by inter simple sequence repeats and only $0.73 \%$ polymorphic bands were detected by amplified fragment length polymorphism. The morphologies of the regenerants were identical to those of the control. Kumar et al. (2016) used axillary bud, callus and somatic embryos to develop new plants of Dianthus caryophyllus cv. Yellow Dot Com. The plants regenerated from axillary buds, callus and somatic embryos were compared with mother plant to assess genetic fidelity using RAPD and $2.94 \%, 26.47 \%$ and $20.58 \%$ variation was observed, respectively. Rashmi et al. (2018) studied genetic fidelity of in vitro raised gerbera plants by using 


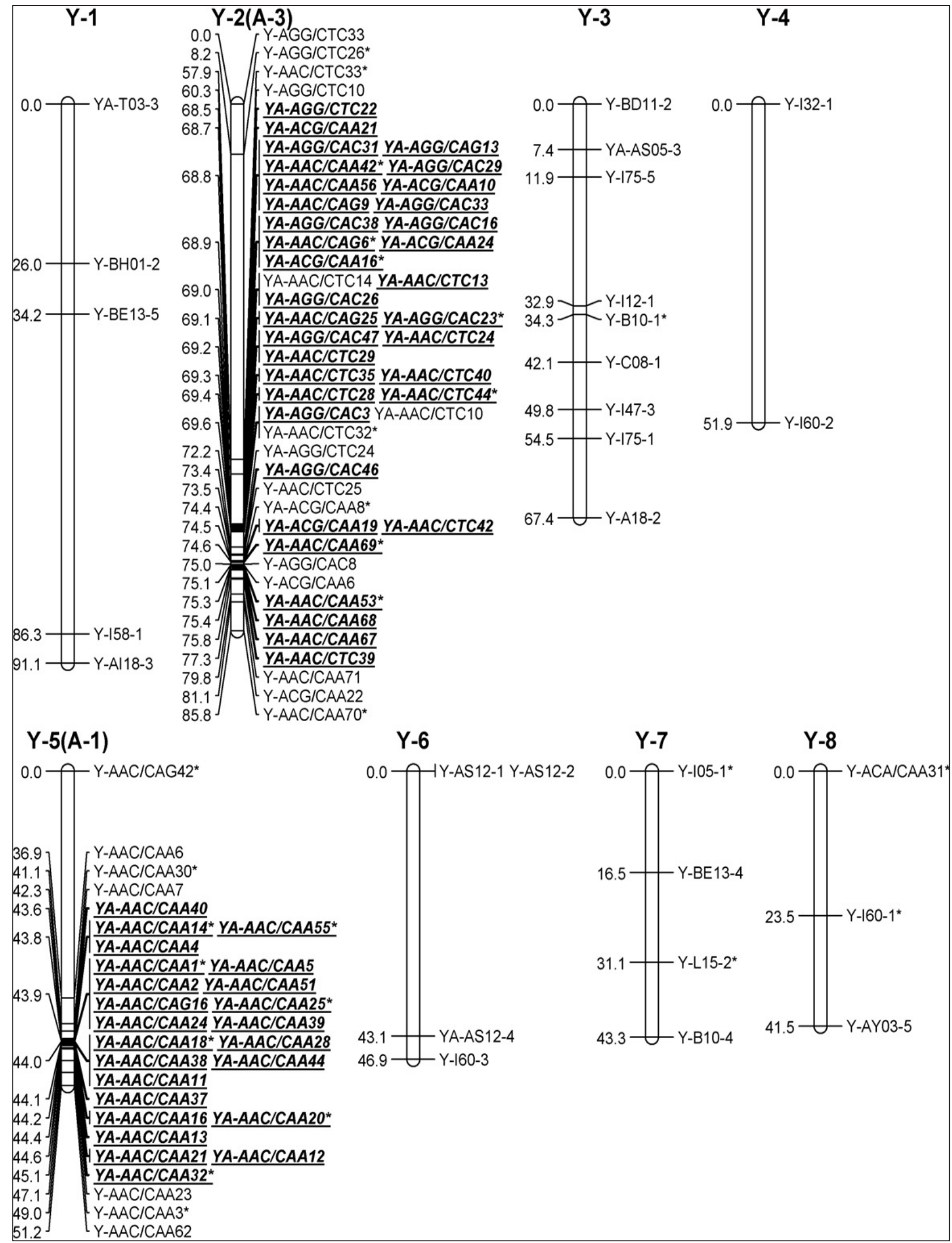

Fig. 4: Genetic linkage map for chrysanthemum cultivar 'Yuhualuoying' constructed with testcross markers heterozygous in 'Yuhualuoying' and intercross markers heterozygous in both parents using a combination of RAPD, ISSR and AFLP markers (Zhang et al. 2010) 


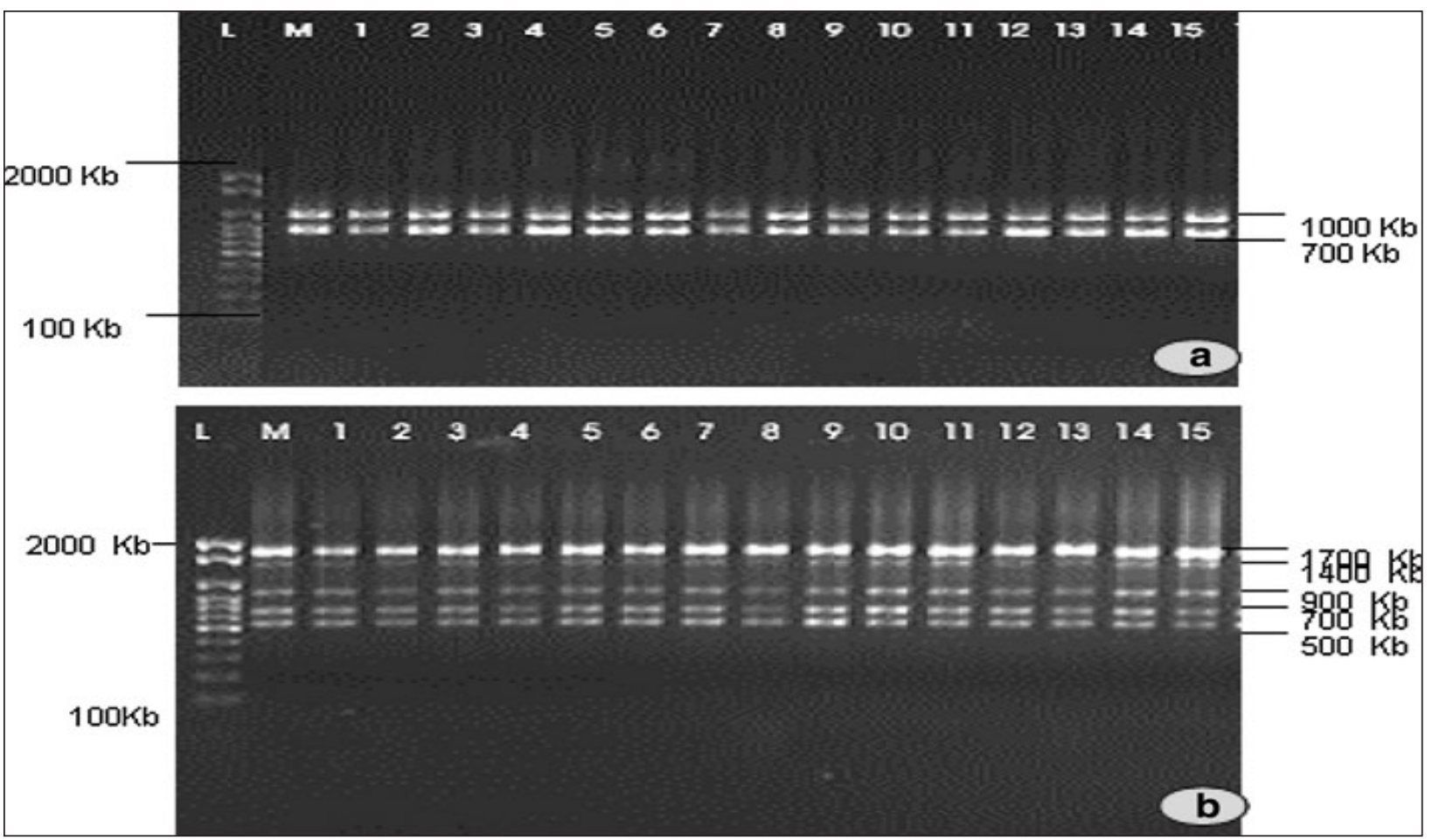

Fig. 5: Polymerase chain reaction (PCR) amplification products obtained with a random amplified polymorphic DNA (RAPD) primer (OPE-01) and b inter simple sequence repeat (ISSR) primer (ISSR-06). Lane L represents 100-bp ladder, lane M represents the mother plant and lanes 1-15 represent in vitro-raised clones derived from capitulum explants of gerbera (Bhatia et al. 2011)

inter-simple sequence repeat (ISSR) markers. Initially, a total of 40 ISSR primers screened, out of 20 ISSR primers were finally selected and used to fidelity analysis of in vitro raised gerbera. A total of 54 ISSRs clear, distinct and reproducible mono-morphic amplicons were produced across all micro-propagated plants. All banding profiles from micro-propagated plants were monomorphic and similar to those of the mother plant. It's indicated that the developed of micro-propagation protocol for rapid in vitro multiplication was appropriate and suitable for clonal propagation in gerbera.

Tikendra et al. (2019a) investigated genetic homogeneity testing of micro-propagated Dendrobium chrysotoxum using 12 random amplified polymorphic DNA (RAPD) and 11 inter-simple sequence repeat (ISSR) primers. Molecular marker analysis unveiled high genetic mono-morphism $(96.30 \%)$ and low genetic polymorphism (3.6\%) among the in vitro clones and mother plant. Nei's genetic distance ranged from 0.00 to 0.037 disclosing high genetic similarity between the clones. Dendrograms generated from RAPD and ISSR marker analysis also revealed high genetic proximity with mother plant and micro-propagated clones. Principal coordinate analysis (PCoA) further confirmed the grouping of plants in accordance with the cluster analysis determined by unweighted pair group method using arithmetic averages (UPGMA) analysis. Tikendra et al. (2019b) used Random Amplified Polymorphic DNA (RAPD) and Inter Simple Sequence Repeats (ISSR) markers to assess genetic homogeneity assessment of micro-propagated Dendrobium moschatum. Analysis showed $95.2 \%$ and $98 \%$ genetic mono-morphism respectively among in vitro regenerants and the mother plant. Nei's genetic distance ranged from 0.00 to 0.044 disclosing high genetic similarity among the regenerants. The Unweighted Pair Group Method with Arithmetic Mean (UPGMA) based dendrograms generated from RAPD and ISSR marker analysis also revealed high genetic proximity between mother and micro-propagated plants. Principal Coordinate Analysis (PCoA) further confirmed the grouping of plants in accordance with UPGMA dendrograms. Correlation analysis between the matrices of markers revealed higher efficiency of ISSR over RAPD markers. 


\section{CONCLUSION}

The literature covered in this review provides important new insights into the applied use of molecular technologies and markers in various flowering crops, including for genetic diversity, interrelationship between the genotypes, genetic purity, DNA barcode, tagging of important genes, development of linkage maps, marker assisted selection and application of molecular markers in tissue culture of floricultural crops. Molecular markers have been employed in genetic studies of various floricultural crops. However, our knowledge of the inheritance of important floricultural crops characteristics is still limited and molecular markerassisted breeding is still in its infancy in floricultural crops. The full potential of various molecular markers has not yet been realized in floricultural crops. Reproducibility, accuracy, co-dominance, high polymorphism and low cost are the characteristics of a good marker system.

Further progress in floriculture crop breeding can be made by crosses with more distant genotypes as sources of new genetic variability, with new introgressions of important loci for resistance and quality. The identification of SSR, SNP or QTL markers in known-function genes linked to specific traits can facilitate marker-assisted selection. One important task is to develop a platform for floriculture crop genotyping, employing genomewide distributed SNP markers. Map-based cloning of important resistance genes will be realistic. A high level of synteny between related species found by comparative mapping in other species like maize, rice and Arabidopsis, will shade light on floricultural crops to speed up the understanding of genome organization and gene identification process. As molecular markers become less expensive, and more efficient development strategies make them more informative, more research should be conducted on floricultural crops to obtain insight into the genetics and biological processes of key traits in floricultural crops.

\section{ACKNOWLEDGMENTS}

The authors are thankful to the Department of Horticulture, Sardar Vallabhbhai Patel University of Agriculture \& Technology, Meerut (U.P.), India and J-gate a sources of $\mathrm{E}$ - journls for providing some papers to preparation of this review.

\section{REFERENCES}

Baliyan, D., Sirohi, A., Singh, D., Kumar, M., Malik, S. Singh, M.K. 2014a. Molecular chracterization of Chrysanthemum (Chrysanthemum morifolium Ramat) germplasm using RAPD markers. Journal of Plant Development Sciences, 6(3): 389-395.

Baliyan, D., Sirohi, A., Singh, D., Kumar, M., Malik, S. and Singh, M.K. 2014b. Assessment of genetic diversity in Chrysanthemum (Chrysanthemum morifolium Ramat) germplasm using Microsatellite markers. Journal of Plant Development Sciences, 6(3): 397-403.

Baliyan, D., Sirohi, A., Kumar, M., Kumar, V., Malik, S., Sharma, S. and Sharma, S. 2014c. Comparative genetic diversity analysis in chrysanthemum: A pilot study based on morphoagronomic traits and ISSR markers. Scientia Hort., 167: 164-168.

Ballard, R., Rajapakse, S., Abbott, A. and Bryne, D.H. 1996. DNA markers in rose and their use for cultivar identification and genome mapping. Acta Hortic., 424: 265.268 .

Barik, S., Senapati, S.K., Subhashree-Aparajita, Mohapatra, A. and Rout, G. 2006. Identification and genetic variation among Hibiscus species (Malvaceae) using RAPD markers. Biosciences, 61(1): 123-128.

Biber, A., Kaufmann, H. Linde, M. Spiller, M., Terefe, D. and Debener, T. 2010. Molecular markers from a BAC contig spanning the Rdr 1 locus: a tool for marker-assisted selection in roses. Theor. Appl. Genet., 4: 765-773.

Behroozian, M., Jafari, A. and Farsi, M. 2013. RAPD analysis of genetic variation within and among natural populations of two species of Dianthus L. (Caryophyllaceae) in NE Iran. Iran. J. Bot., 19(2): 194-201.

Bhatia, R., Singh, K.P., Sharma, T.R. and Zhang, T. 2011. Evaluation of the genetic fidelity of in vitro-propagated gerbera (Gerbera jamesonii Bolus) using DNA-based markers. Plant Cell Tiss Organ Cult., 104: 131-135.

Bhattacharyya, P. and Kumaria, S. 2015. Molecular characterization of Dendrobium nobile Lindl., an endangered medicinal orchid, based on randomly amplified polymorphic DNA. Plant Syst. Evol., 301(1): 201-210.

Botstein, D., White, R.L., Skolnick, M. and Davis, R.W. 1980. Construction of a genetic linkage map in man using restriction fragment length polymorphisms. Am. J. Hum. Genet., 32: 314 -331.

Braglia, L., Bruna, S., Lanteri, S., Mercuri, A. and Portis, E. 2010. An AFLP-based assessment of the genetic diversity within Hibiscus rosa-sinensis and its place within the Hibiscus genus complex. Scientia Horticulturae, 123: 372-378.

Chatterjee, J., Mandal, A.K. A., Chakrabarty, D. and Datta, S.K. 2007. Use of RAPD analysis to determine genetic diversity and relationships among Bougainvillea cultivars at inter-specific levels. Horticulture, Environment, and Biotechnology, 48: 43-51. 
Chase, M.W., Salamin, N., Wilkinson, M., Dunwell, J.M., Kesanakurthi, R.P., Haidar, N. and Savolainen, V. 2005. Land plants and DNA barcodes: short-term and long term goals. Philos. Trans. R. Soc. Lond. Bull. Biol. Sci., 360: 1889-1895.

Chaudhary, V., Kumar, M., Sharma, S., Kumar, N., Kumar, V., Yadava, H.K., Sharma, S. and Sirohi, U. 2018. Assessment of genetic diversity and population structure in gladiolus (Gladiolus hybridus Hort.) by ISSR markers. Physiology and Molecular Biology of Plants, 24(3): 493-501.

Chen, M., Hong; Z. Kaijing, T., Kexuan, T. and Dongqin, Z. 2009. Genetic diversity analysis of Lilium spp. germplasms by RAPD. J. of Shanghai Jiaotong Uni., 27(5): 475-479.

Chong, X., Zhang, F., Wu, Y., Yang, X., Zhao, N., Wang, H., Guan, Z., Fang, W., Chen, F. A. 2016. SNP-Enable assessment of genetic diversity, evolutionary relationships and the identification of candidate genes in chrysanthemum. Genome Biol Evol., 8: 3661-3671.

Chong, X., Su, J., wang, F., Wang, H., Song, A., Guan, Z., Fang, W., Jiang, J., Chen, S., Chan, F. and Zhang, F. 2019. Identification of favorable SNP alleles and candidate genes responsible for inflorescence-related traits via GWAS in chrysanthemum. Plant Molecular Biology, 99(4\&5): 407-420.

Chowdhury, M.A., Vandenberg, V. and Warkentin, T. 2002. Cultivar identification and genetic relationship among selected breeding lines and cultivars in chick pea (Cicer arietinum L). Euphytica, 127(3): 317-325.

de Vere, N., Rich, T.C.G., Ford, C.R., Trinder, S.A., Long, C. et al. 2012. DNA Barcoding the native flowering plants and conifers of wales. PLoS ONE, 7(6): e37945.

Dore, C., Dosba, F. and Baril, C. (eds.) 2001. Proceedings of the international symposium on molecular markers for characterizing genotypes and identifying cultivars in horticulture. Acta Hort. 546, Leuven, Belgium.

Elansary, H., Ashfaq, M., Ali, H.M. and Yessoufou, K. 2017. The first initiative of DNA barcoding of ornamental plants from Egypt and potential applications in horticulture industry. PLOS ONE, 12(2): e0172170.

Feng, S.G., Zhao, H.Y., Lu, J.J., Liu, J.J., Shen, B. and Wang, H.Z. 2013. Preliminary genetic linkage maps of Chinese herb Dendrobium nobile and D. moniliforme. J. Genet., 92(2): 205-212.

Gantait, S. and Sinniah, U.R. 2011. Morphology, flow cytometry and molecular assessment of ex-vitro grown micropropagated anthurium in comparison with seed germinated plants. African Journal of Biotechnology, 10(64): 13991-13998.

Gould, A.R. 1986. Factors controlling generation of variability in vitro. In: Vasil IK (ed) Cell Culture and Somatic Cell Genetics in Plants. 3. Plant Regeneration and Genetic Variability (pp. 549-567). Academic Press, Orlando

Gulsen, O., Karagul, S. and Abak K. 2007. Diversity and relationships among Turkish okra germplasm by SRAP and phenotypic marker polymorphism. Biologia, 62: 41-45.

Gupta, A., Maurya, R., Roy, R.K., Sawant, S.V., and Yadav, H.K. 2013. AFLP based genetic relationship and population structure analysis of Canna-An ornamental plant. Scientia Horticulturae, 154: 1-7.

He, G.H. and Prakash, C. 2001. Evaluation of genetic relationships among botanical varieties of cultivated peanut (Arachis hypogaea L.) using AFLP markers. Genet Resour Crop Evol., 48: 347-352.

Huang, H., Li, J.S., Fu, A.J. and Yan, H. 2010. Screening of potential DNA barcoding marks in Dendrobium. Chin. J. Trop. Crops, 31(10): 1769-1777.

Jędrzejuk, A., Meyer, L. and Serek, M. 2017. Characterization of interspecific hybrids of Petunia and Calibrachoa by multiplex PCR, DNA content, and chromosome number. The Journal of Horticultural Science and Biotechnology, 92(5): 493-501.

Jingang, W., Liu, C.D., Yang, S.K. and Pin, C. 2008a. RAPD analysis of twenty-six general species in (Gladiolus hybridus Hort.) Bulletin of Botanical Research, 28(3): 321-324.

Jingang, W., Ying, G., Daidi, C., Shenkui, L. and Chuanpin, Y. 2008b. ISSR analysis of 26 general species in Gladiolus Hybridus Hort. Journal of Northeast Agricultural University 15(4): 6-10.

Kameswari, P.L., Girwani, A. and Radha Rani, K. 2014. Genetic diversity in tuberose (Polianthes tuberosa Linn.) using morphological and ISSR markers. Electronic Journal of Plant Breeding, 5(1): 52-57.

Khandagale, K., B. Padmakar, D.C., Lakshmana Reddy, A. Sane, S. and Aswath, C. 2014. Genetic diversity analysis and barcoding in tuberose (Polianthes tuberosa L.) cultivars using RAPD and ISSR markers. J. Hortl. Sci., 9(1): 5-11.

Kiani, M., Memariani, F. and Zarghami, H. 2014. Molecular analysis of species of Tulipa L. from Iran based on ISSR marker, Plant Syst. Evol., 298: 1515-1522.

Kimura, T., Yagi, M., Nishitani, C., Onozaki, T., Ban, Y. and Yamamoto, T. 2009. Development of SSR markers in carnation (Dianthus caryophyllus). J. Japan Soc Hort Sci, 78: 115-123.

Kumar, M., Sharma, V.R., Kumar, N., Sirohi, U., Naresh, R.K. and Chaudhary, V. 2017. Screening of Microsatellite markers for genetic diversity assessment and conservation of germplasm in Okra (Abelmoschus esculents L.) Moench. Int. J. Curr. Microbiol. App. Sci., 6(6): 509-520.

Kumar, M., Sharma, V.R, Kumar, V., Sirohi, U. Chaudhary, V., Sharma, S., Saripalli, G., Naresh, R.K., Yadava, H.K. and Sharma, S. 2019. Genetic diversity and population structure analysis of Indian garlic (Allium satioum L.) collection using SSR markers. Physiology and Molecular Biology of Plants, 25(2): 377-386.

Kumar, M., Chaudhary, V., Sharma, V.R., Sirohi, U. and Singh, J. 2018a. Advances in biochemical and molecular marker techniques and their applications in genetic studies of orchid: A review. International Journal of Chemical Studies, 6(6): 806-822.

Kumar, M., Chaudhary, V., Sirohi, U., Singh, M.K., Malik, S. and Naresh, R.K. 2018b. Biochemical and molecular markers for characterization of chrysanthemum germplasm: A review. Journal of Pharmacognosy and Phytochemistry, 7(5): 2641-2652. 
Kumar, S., Kumari, R., Baheti, T., Thakur, M. and Ghani, M. 2016. Plant regeneration from axillary bud, callus and somatic embryo in carnation (Dianthus caryophyllus) and assessment of genetic fidelity using RAPD-PCR analysis. Indian Journal of Agricultural Sciences, 86(11): 1482- 1488.

Kumar, P., Kumar, M., Naresh, R.K., Kumar, N., Chaudhary, P. and Sharma, S. 2016. Evaluation of genetic diversity among gladiolus (Gladiolus hybridus hort.) Germplasm using ISSR markers. Int. J. Agricult. Stat. Sci., 12(1): 277-283.

Kumar, P.V., Janakiram, T., Bhat, K.V., Jain, R., Prasad, K.V., and Prabhu, K.V. 2014. Molecular characterization and cultivar identification in Bougainvillea spp. using SSR markers. Indian Journal of Agricultural Sciences, 84(8): 1024-30

Kumar, R., Kumar, M., Sharma, S., Gangwar, T.S., Singh, S. and Tomar, V. 2013. Estimation of genetic variability among papaya (Carica papaya L.) germplasm using RAPD markers. Annals of Horticulture, 6(2): 260-266.

Kumar, R., Kumar, Singh A.K, Kumar, A., Kumar, B., Pratap, B., Rana, M.S., Kumar, M. and Kumar, M. 2014. Molecular characterization of mango (Mangifera indica L) using RAPD markers. Annals of Horticulture, 7(1): 17-19.

Kumar, S., Kumar, M., Yadav, H.K., Sharma, S. and Kumar, S. 2017. Genetic diversity and population structure analysis of chrysanthemum (Dendranthema grandiflora Tzvelev) germplasm based on RAPD markers. Journal of Environmental Biology, 38: 457-464.

Kumar, V., Sharma, S., Kero, S., Sharma, S., Sharma, A.K., Kumar, M. and Bhat, K.V. 2008. Assessment of genetic diversity in common bean (Phaseolus vulgaris L) germplasm using amplified fragment length polymorphism (AFLP). Scientia Horticulturae, 116: 138-143

Kumar, V., Sharma, S., Sharma, A.K, Kumar, M., Sharma, S., Malik, S., Singh, K.P., Sanger, R.S. and Bhat, K.V. 2008. Genetic diversity in Indian common bean (Phaleous vulgaris L.) using random amplified polymorphic DNA markers. Physiol. Mol. Biol. Plants, 14(4): 383-387.

Lee, S.Y., Yae, B.W. and Kim, K.S. 2005. Segregation patterns of several morphological characters and RAPD markers in interspecific hybrids between Dianthus giganteus and D. carthusianorum. Scientia Horticulturae, 105: 53-64.

Lefort-Buson, M., Rodolphe, F. and Charcosset, A. 1990. De nouvelles perspectives pour I'analyse génétique des caractères quantitatifs. 1. À la recherche des locus importants. Biofutur, 91: 30-7.

Lema-Ruminska, J., Zalewska, M. and Sadoch, Z. 2004. Radiomutants of chrysanthemum (Dendranthema grandiflora Tzvelev) of the Lady group: RAPD analysis of the genetic diversity. Plant Breed., 123: 290-293.

Li, C.N., Fu, Q.J., Chen, Y., Zhao, F.K., Sun, Y. and Cui, H.R. 2014. Analysis of genetic diversity of the major Tagetes patula varieties in China using SRAP markers. Zhiwu Shengli Xuebao/Plant Physiology Journal, 50(9): 1429-1434

Li, Q., Xu, J., Han, L., Gao, C., Lu, J., Du, G. and Sun X. 2017. Evaluation of ITS2 for intraspecific identification of Paeonia lactiflora cultivars. Biotechnology Reports, 15: 101-106
Linde, M., Mattiesch, L. and Debener, T. 2004. Rpp1, a dominant gene providing race-specific resistance to rose powdery mildew (Podosphaera pannosa): molecular mapping, SCAR development and confirmation of disease resistance data. Theoretical and Applied Genetics, 109: 1261-1266.

Liu, F., Huang, L.L., Yang, L.L., Reinhoud, P., Jongsma, M.A. and Wang, C.Y. 2011. Shoot organogenesis in leaf explants of Hydrangea macrophylla 'Hyd1' and assessing genetic stability of regenerants using ISSR markers. Plant Cell Tiss Organ Cult, 104: 111-117.

Lu, J.J., Zhao, H.Y., Suo, N.N., Wang, S., Shen, B., Wang, H.Z., Liu, J.J. 2012. Genetic linkage maps of Dendrobium moniliforme and D. officinale based on EST-SSR, SRAP, ISSR and RAPD markers. Scientia Horticulturae, 137: 1-10.

Malek, B., Weber, W.E. and Debener, T. 2000. Identification of molecular markers linked to $R d r 1$, a gene conferring resistance to blackspot in roses. Theoretical and Applied Genetics, 101(5/6): 977-983.

McDonald, M.B. 1995. Genetic purity: from protein electrophoresis to RAPDs. In: the fiftieth annual corn \& sorghum industry research conference, pp. 256-271.

Memon, N., Qasim, M., Jaskani, M.J., Awan, F.S., Khan, A.I., Sadia, B. and Hussain, Z. 2012. Assessment of somaclonal variation in in vitro propagated cormels of gladiolus. Pak. J. Bot., 44: 769-776.

Nadeem, M.A., Nawaz, M.A., Shahid, M.Q., Doğan, Y., Comertpay, G., Yıldız, M., Hatipoğlu, R., Ahmad, F., Alsaleh, A., Labhane, N., Özkan, H., Chung, G. and Baloch, F.S. 2018. DNA molecular markers in plant breeding: current status and recent advancements in genomic selection and genome editing. Biotechnology $\mathcal{E}$ Biotechnological Equipment, 32(2): 261-285.

Onozaki, T., Ikeda, H., Tanikawa, N., Shibata, M., Kudo, K. and Funayama, T. 2003. Identification of random amplified polymorphicDNA markers linked to bacterial wilt resistance in carnations. Acta Horticulturae, 612: 95-103.

Panwar, S., Singh, K.P., Janakiram, T., Bhardwaj, C., Banyal, N., Sonah, H., Deshmukh, R and Sharma, T. 2017. Molecular characterization of African marigold (Tagetes erecta L.) genotypes using RAPD markers. Indian Journal of Agricultural Sciences, 87(5): 663-668.

Parveen, I., Singh, H.K., Raghuvanshi, S., Pradhan, U.C., Babbar, S.B., 2012. DNA barcoding of endangered Indian Paphiopedilum species. Mol. Ecol. Res., 12(1): 82-90.

Patra, B., Acharya, L., Mukherjee, A.K., Panda, M.K. and Panda, C.P. 2008. Molecular characterization of ten cultivars of Canna lilies (Canna Linn.) using PCR based molecular markers (RAPDs and ISSRs). Int. J. Integr. Biol., 2: 129-137.

Pejic, I., Ajmone-Marsan, P., Morgante, M., Kosumplick, V., Castiglioni, P. Taramino, G.and Motto, M. 1998. Comparative analysis of genetic similarity among maize inbred lines detected by RFLPs, RAPDs, SSRs, and AFLPs. Theor. Appl. Genet., 97: 1248 - 1255. 
Phillips, R.L., Kaeppler, S.M. and Olhoft, P. 1994. Genetic instability of plant tissue cultures: Breakdown of normal controls. Proc. Natl. Acad. Sci. USA., 91: 5222-5226.

Pragya, Bhat, K.V., Misra, R.L. and Ranjan, J.K. 2010. Analysis of diversity and relationships among Gladiolus cultivars using morphological and RAPD markers. Ind. J. Agric. Sci., 80(9): 766-72.

Prasad, M.P. 2014. Molecular characterization and genetic diversity determination of Hibiscus species using RAPD molecular markers. Asian J. Plant Sci. Res., 4(3): 50-56.

Qi, Y.C., Ning, G.G. and Bao, M.Z. 2007. Evaluation of genetic relationships of Tagetes patula inbred lines using ISSR markers and morphological traits. Scientia Agricultura Sinica, 40(6): 1236-1241.

Ranjan, P., Bhatt, K.V., Misra, R.L., Singh, S.K. and Ranjan, J.K. 2010. Genetic relationships of gladiolus cultivars inferred from fluorescence based AFLP markers Scientia Hort., 123: 562-567.

Rashmi, R., Aswath, C., Dhananjaya, M.V. and Lakshmana Reddy, D.C. 2018. Assessment of Genetic Fidelity of Micropropagated Gerbera (Gerbera jamesonii Bolus) Plants by ISSR Markers. Int. J. Curr. Microbiol. App. Sci., 7(12): 508-514

Schafleitner, R., Kumar, S., Lin, C., Hegde, S.G. et al. 2013. The okra (Abelmoschus esculentus) transcriptome as a source for gene sequence information and molecular markers for diversity analysis. Gene, 517: 27-36.

Scovel, G., Ben-Yephet, Y., Ovadis, M., Reuven, M. and Vainstein, M. 2001. Markers assisted selection for resistance to Fusarium oxysporum in the greenhouse carnation. Acta Hort., 552: 151-156.

Senapati, S.K. and Rout,G.R. 2008. In vitro mutagenesis of rose with ethyl methane sulphonate (EMS) and early selection using RAPD markers. Ad. Hort. Sci., 22(3): 218.222.

Shahin, A., Arens, P., Van Heusden, S. and Van Tuyl, J.M. 2009. Conversion of molecular markers linked to Fusarium and virus resistance in Asiatic lily hybrids. Acta Hort., 836: $131-136$

Shahin, A., Arens, P., Van Heusden, A.W., Van Der Linden, G., Van Kaauwen, M., Khan, N., Schouten, H.J., Van De Weg, W.E., Visser, R.G.F. Van Tuyl, J.M. 2011. Genetic mapping in Lilium: mapping of major genes and quantitative trait loci for several ornamental traits and disease resistances. Plant Breed., 130: 372-382.

Sharma, V.R., Malik, S., Kumar, M., Sirohi, A. and Nagraju, K. (2016) Assessment of genetic diversity in garlic (Allium sativum L.) genotypes based on ISSR markers. Plant Archives, 16(1): 88-95.

Singh, H.K., Parveen, I., Raghuvanshi, S. and Babbar, S.B. 2012. The loci recommended as universal barcodes for plants on the basis of floristic studies may not work with congeneric species as exemplified by DNA barcoding of Dendrobium species. BMC Res. Notes, 5: 42.

Singh, N., Pal, A.K., Roy, R.K., Tewari, S.K., Tamta, S. and Rana, T.S. 2016. Assessment of genetic variation and population structure in Indian gladiolus cultivars inferred from molecular markers. The Nucleus, 59: 235-244.

Sirohi, U., Kumar, M., Chauhan, P., Kumar, N., Prakash, S., Chand, P., Naresh, R. K., Sharma, V. R. and Chaudhary V. 2017a Genetic diversity in tuberose (Polianthes tuberosa L.) germplasm using Inter Simple Sequence Repeat (ISSR) markers. Int. J. Curr. Microbiol. App. Sci., 6(5): 1313-1321.

Sirohi, U., Kumar, M., Kumar, P., Singh, M.K., Kumar, N., Prakash, S., Chand, P., Naresh, R.K., Sharma, V.R. and Chaudhary, V . 2017b. Genetic diversity in single and double type of tuberose (Polianthes tuberosa L.) germplasm using randomoly amplified polymorphic DNA (RAPD) markers. Int. J . Agric. Stat. Sci., 13(2): 519-526.

Smith, J.L., Hunter, K.L. and Hunter, R.B. 2002. Genetic variations in terrestrial orchid Tipularia discolor. Southeastern Naturalist, 1(1): 17-26.

Soltis, D.E. and Soltis, P.A. (eds.) 1990. Isozymes in plant biology (Advances in Plant Sciences Series, Vol. 4). Tyimber Press, Portland.

Srivastava, R., Shukla, S., Soni, A. and Kumar, A. 2009. RAPDbased genetic relationships in different Bougainvillea cultivars. Crop Breeding and Applied Biotechnology, 9: 154-163.

Tasaki, K., Higuchi, A., Fujita, K. Watanabe, A., Sasaki, N., Fujiwara, K., Abe, H., Naito, Z., Takahashi, R., Hikage, T. and Nishihara, M. 2017. Development of molecular markers for breeding of double flowers in Japanese gentian. Molecular Breeding, 37: 33.

Tikendra, L., Singh, A.K. and Nongdam, K.P. 2019a. Molecular markers based genetic fidelity assessment of micropropagated Dendrobium chrysotoxum Lindl. Meta Gene, 20: 100562.

Tikendra, L., Singh, A.K. and Nongdam, K.P. 2019b. Molecular genetic homogeneity assessment of micropropagated Dendrobium moschatum Sw. - A rare medicinal orchid, using RAPD and ISSR markers. Plant Gene, 19: 100196.

Turchetto, C., Segatto, A.L.A., Beduschi, J. Bonatto, S.L. and Freitas, L.B. 2015. Genetic differentiation and hybrid identification using microsatellite markers in closely related wild species. AoB PLANTS, 7: plv084.

Van Heusden, A.W., Jongerius, M.C., Van Tuyl, J.M., Straathof, T.P. and Mes, J.J. 2002. Molecular assisted breeding for disease resistance in lily. Acta Hortic., 572: 131-138.

Vogler, A.P., Monaghan, M.T., 2007. Recent advances in DNA taxonomy. J. Zool. Syst. Evol. Res., 45(1): 1-10.

Wang, H.Z., Feng, S.G., Lu, J.J., Shi, N.N. and Liu, J.J. 2009. Phylogenetic study and molecular identification of 31 Dendrobium species using inter-simple sequence repeat (ISSR) markers. Sci. Hortic., 122(3): 440-447.

Wang, Z., Yin, D., Wang, P., Zhao, J., Pan, B. and Zhang, H. 2010. RAPD markers developed for identifying male sterility in Tagetes erecta. Acta Hort., 855: 289-294.

Xiang, N. and Hong, Y. 2003. Genetic analysis of tropical orchid hybrids (Dendrobium) with Fluorescence Amplified Fragment-length Polymorphism (AFLP). J. Amer. Soc. Hort. Sci., 128(5): 731-735. 
Xue, D.W., Feng, S.G., Zhao, H.Y., Jiang, H., Shen, B., Shi, N.N., Lu, J.J., Liu, J.J. and Wang, H.Z. 2010. The linkage maps of Dendrobium species based on RAPD and SRAP markers. J. Genet. Genom., 37(3): 197-204.

Yadav, C.S., Kumar, M., Singh, D., Kumar, N., Singh, M.K., Singh, K.V. and Malik, S. 2015. Assessment of genetic diversity and genetic relationship of garlic (Allium sativum L.) germplasm based on Microsatellite markers. HortFlora Res. Spectrum, 4(4): 301-307.

Yamagishi, M. 1995. Detection of section-specific random amplified polymorphic DNA (RAPD) markers in Lilium. Theor Appl Genet., 91(6-7): 830-835.

Yan, M.Q.et al. 2018. Genotyping-by-sequencing application on diploid rose and a resulting high-density SNP-based consensus map. Hortic. Res-England, 5: 17.

Yao, H., Song, J.Y., Ma, X.Y., Liu, C., Li, Y., Xu, H.X., Han, J.P., Duan, L.S. and Chen, S.L. 2009. Identification of Dendrobium species by a candidate DNA barcode sequence, the chloroplast psbA-trnH intergenic region. Planta Med., 75(6): 667-669.
Yin, Z.F., Zhao, B., Bi,W.L., Chen, L. and Wang, Q.C. 2013. Direct shoot regeneration from basal leaf segments of Lilium and assessment of genetic stability in regenerants by ISSR and AFLP markers. In Vitro Cell Dev Biol Plant, 49: 333-342.

Yu, H., He, R., Ni, N.C. and Zhang, S.G. 2004. Fingerprinting analysis of plants of Dendrobium Sw. by AFLP. Chin. Trad. Herbal Drugs, 35(7): 808-810 (in Chinese with English abstract).

Zaman, A., Islam, R. and Joarder, O.I. 1997. Field performance and biochemical evaluation of micropropagated mulberry plants. Plant Cell, Tissue and Organ Culture, 51: 61-64.

Zhang, F., Chen, S.M., Chen, F.D., Fang, W.M. and Li, F.T. 2010. A prelim-inary genetic linkage map of chrysanthemum (Chrysanthemum morifolium) cultivars using RAPD, ISSR and AFLP markers. Sci. Hortic., 125: 422-428.

Zheng, T., Qin, B., Li, S., Cai, M., Pan, H., Wang, J. Cheng, T and Zhang, Q. 2019. Screening of applicable ssr molecular markers linked to creeping trait in crape myrtle. Forests, 10: 429 . 
